\title{
Recorregut de recerca geològica i geoambiental per la comarca de l'Anoia (subcomarca de l'Alta Segarra): des de la Panadella a Sant Martí Sesgueioles i a Calaf
}

Josep Maria Mata-Perelló

Joaquim Sanz Balagué

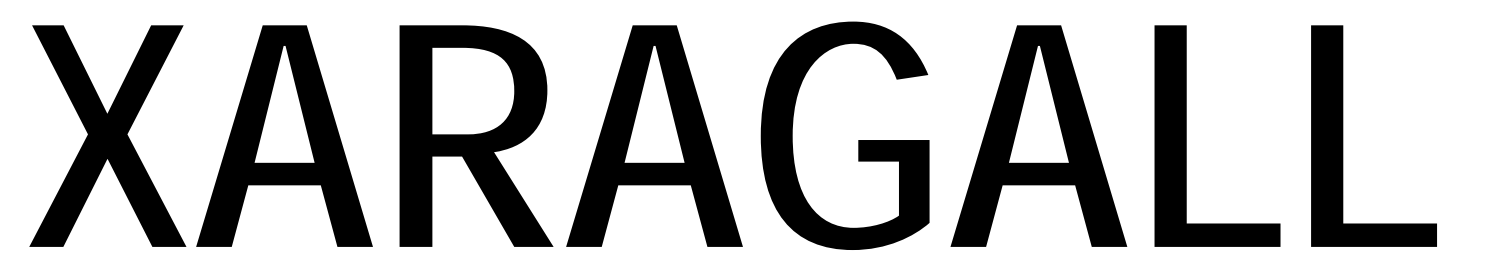

REVISTA DE CIÈNCIES DE LA CATALUNYA CENTRAL

\section{n. 1}

GENER 2015 


\title{
RECORREGUT DE RECERCA GEOLÒGICA I GEOAMBIENTAL PER LA COMARCA DE L'ANOIA (SUBCOMARCA DE L'ALTA SEGARRA): DES DE LA PANADELLA A SANT MARTÍ SESGUEIOLES I A CALAF
}

\author{
Josep Maria Mata-Perelló \\ Museu de geologia Valentí Masachs, Escola Politècnica Superior d'Enginyeria de Manresa \\ (EPSEM), Universitat Politècnica de Catalunya · BarcelonaTech (UPC), 08272 Manresa, Spain
}

\section{Joaquim Sanz Balagué}

Departament d'Enginyeria Minera i Recursos Naturals (EMRN), Escola Politècnica Superior d'Enginyeria de Manresa (EPSEM), Universitat Politècnica de Catalunya . BarcelonaTech (UPC), 08272 Manresa, Spain

Paraules clau: Depressió Geològica de l'Ebre, Materiasl terciaris, Materials quaternaris, Patrimoni miner

\section{Resum}

Itinerari realitzat el 2 de febrer de 2014. En aquesta ocasió, es realitzarà un recorregut geològic que discorrerà en la seva totalitat per diferents indrets de la Depressió Geològica de l'Ebre; i més concretament pels sectors corresponents a la seva Depressió Central, a l'igual que en els altres recorreguts que hem fet per la comarca de l'Anoia.

D'aquesta manera, tot el recorregut transitarà entre afloraments dels materials terciaris (de I'Oligocè) i quaternaris que reblen aquesta depressió. Així, durant tot el recorregut, anirem trobant afloraments que corresponen als materials de la Formació Tàrrega, situant-se íntegrament dintre del Complex Lacustre de la Segarra. Així, veurem terrenys calcolutitics, carbonatats, argilosos i lignits, fonamentalment, al llarg de tot el recorregut de l'itinerari.

Per d'altra banda, el recorregut transitarà inicialment per la comarca d'Anoia, pels sectors septentrionals i segarrencs de la comarca. Després, penetrarà breument a la comarca de la Segarra, per a tornar finalment a la comarca d'Anoia, discorrent els darrers trams del recorregut per la subcomarca de I'Alta Segarra (la també anomenada Segarra Calafina). 


\section{Objectius fonamentals}

Els objectius fonamentals que es pretenen aconseguir en aquest itinerari, es poden concretar en els següents aspectes generals:

1. Observació i descripció dels materials terciaris (exclusivament del Paleogen, i més concretament de I'Oligocè) de la Depressió Geològica de l'Ebre (i més exactament de la seva Depressió Central). Així, el recorregut de l'itinerari discorrerà íntegrament entre els afloraments del materials la Formació Tàrrega, dintre d'aquesta formació, es veuran afloraments eminentment carbonatats, de calcolutites, calcàries, argiles i lignits.

2. Observació de les estructures locals de la Depressió Geològica de l'Ebre, al llarg del recorregut de l'itinerari.

3. Observació de les diferents explotacions mineres que anem trobant al llarg del recorregut de l'itinerari, especialment de les calcàries (a la Panadella i a Segur); dels lignits (a la Guàrdia Pilosa i també a Segur), entre altres indrets; i també de les calcolutites (al terme de Calaf).

4. Observació, si s'escau de les restauracions dutes a terme en les explotacions anteriors, de cara a recuperar el medi natural malmès

5. S'observaran, al llarg de tot el recorregut, els diferents elements relacionats amb el Patrimoni Geològic i Miner.

\section{Antecedents}

Pel que fa al recorregut del tram inicial i central del present itinerari, pràcticament no existeixen cap antecedent relatiu al mateix (es tracta del tram de la Panadella a Sant Martí de Sesgueioles); un antecedent nostre és el Mata-Perelló (2014). En canvi, si que hi ha diversos antecedents bibliogràfics nostres, corresponents al darrer tram (entre Sant Martí de Sesgueioles i Calaf); es tracta de: Mata-Perelló 1997, 1999, 2005, 2007a, 2007b, 2010 i 2011).

Pel que fa a la descripció de les mineralitzacions, seguirem fent esment d'alguns altres treballs nostres: Mata-Perelló (1990 i 1991); el primer relatiu a la comarca de l'Anoia, el segon al conjunt de les mineralitzacions catalanes. I, finalment, pel que fa a l'estructura geològica de la zona per la qual discorre l'itinerari, farem esment dels treballs de: Guimerà et altri (1982) i de Riba et altri (1976). També farem esment d'un treball nostre: Mata-Perelló (1985). Tots aquests treballs referenciats, i d'altres, figuren esmentats per ordre alfabètic a l'apartat dedicat a la BIBLIOGRAFIA. 


\section{Recorregut de l'itinerari}

El recorregut de l'itinerari discorrerà inicialment per la comarca d'Anoia. I ho farà per l'entorn de les poblacions de la Panadella i de Montmaneu. En aquesta part del recorregut es transitarà per les carreteres locals: BV - 2234 i B - 221 (pels voltants de la Panadella) i finalment per la B- 100 (anant cap a Montmaneu).

Tot seguit s'entrarà a la comarca lleidatana de la Segarra, circulant-se pels voltants de la Tallada i Sant Guim de Freixenet. Posteriorment, tornarem a entrar a la comarca de la Segarra (en realitat a l'Alta Segarra), circulant ara per la carretera local BV - 1001. Així, passarem pels voltants de Segur i per Sant Martí de Sesgueioles, arribant finalment a Calaf, per on finalitzarà aquest itinerari.

\section{Advertiments previs}

Com en altres recorreguts de RECERCA GEOLÒGICA I MINERALÒGICA... si es disposa del temps suficient, poden efectuar-se passant per totes les parades i filloles. En cas contrari, recomanem prescindir de les anomenades PARADES - CONDICIONALS.

També cal tenir en conte que en algunes parts del recorregut, caldrà fer trams per camins de terra; això si molt pocs i curts, per la qual cosa serà millor fer-los a peu, o buscar informacions sobre l'estat dels camins.

Cal tenir, com sempre, una cura molt especial de respecte a la natura, al llarg de tot el recorregut de l'itinerari, i també fora d'ell.

\section{Descripció de l'itinerari}

Com de costum, estructurarem el recorregut de I'itinerari en una sèrie de PARADES, que anirem veient. En cadascuna d'aquestes aturades farem un breu comentari (geològic 0 mineralògic, segons s'escaigui). En cada cas indicarem, entre parèntesi, el full topogràfic on es troba l'aturada.

En aquest cas, el recorregut de l'itinerari s'inclourà dintre dels següents fulls, del "Mapa Topográfico Nacional", realitzats a l'escala 1:50.000 per I'I.G.C. de España": 361 (o de Cervera, encara que abans es coneixia com a full de Guissona), 362 (o de Sant Joan de Vilatorrada, encara que abans es coneixia com a full de Calaf), 390 (o full de Tàrrega) i 391 (o d'Igualada).

Tanmateix, si s'escau, es pot utilitzar el Mapa Topogràfic Comarcal d'Anoia, editat per l'Institut Cartogràfic de Catalunya.

Així doncs, la relació de les aturades, que composen el recorregut d'aquest itinerari és la següent: 


\subsection{Parada 1. PEDRERA DE CALCÀRIES DE LA PANADELLA - CARBASSÍ, (la Panadella, terme municipal de Montmaneu, comarca de I’Anoia). (Full 390)}

El recorregut l'iniciarem prop del poble de Carbassí; en realitat, entre aquesta localitat i la de la Panadella, a la carretera BV - 2234, que uneix els dos pobles. En aquest indret hi ha unes antigues explotacions de calcàries. Aquí farem la primera de les aturades d"aquest itinerari, a uns $2 \mathrm{Km}$ de cada un dels dos pobles.

En aquest indret afloren uns nivells carbonatats calcaris, les anomenades calcàries de Montmaneu - la Panadella. Al respecte, cal recordar que quests materials formen part de Formació Tàrrega, constitueixen aquí el Sistema lacustre de la Segarra. Aquestes calcàries, per canvi lateral de fàcies passen a la Formació Calaf, la qual es troba amplament representada més cap al NE d'un ara ens trobem. Aquests darrers materials són els que es troben al Port de la Panadella, on constitueixen una suau cinglera, una clara "cuesta. Aquesta cinglera constitueix la divisòria d'aigües entre la vall del Segre, i la de I'Anoia. Així, per sota de les calcàries, cap al Nord, neixen el riu d'Ondara i el riu Corb, tributaris del Segre. Mentre que cap al Sud ho fa el riu Anoia, tributari del Llobregat.

Per d'altra banda, en aquest lloc, on fem la present aturada, hi ha una important explotació a "cel obert" dels nivells carbonatats dels quals hem acabat de parlar. Aquestes calcàries, en bona part s'utilitzen $\mathrm{cm}$ a àrids. (fotografia 1 ).

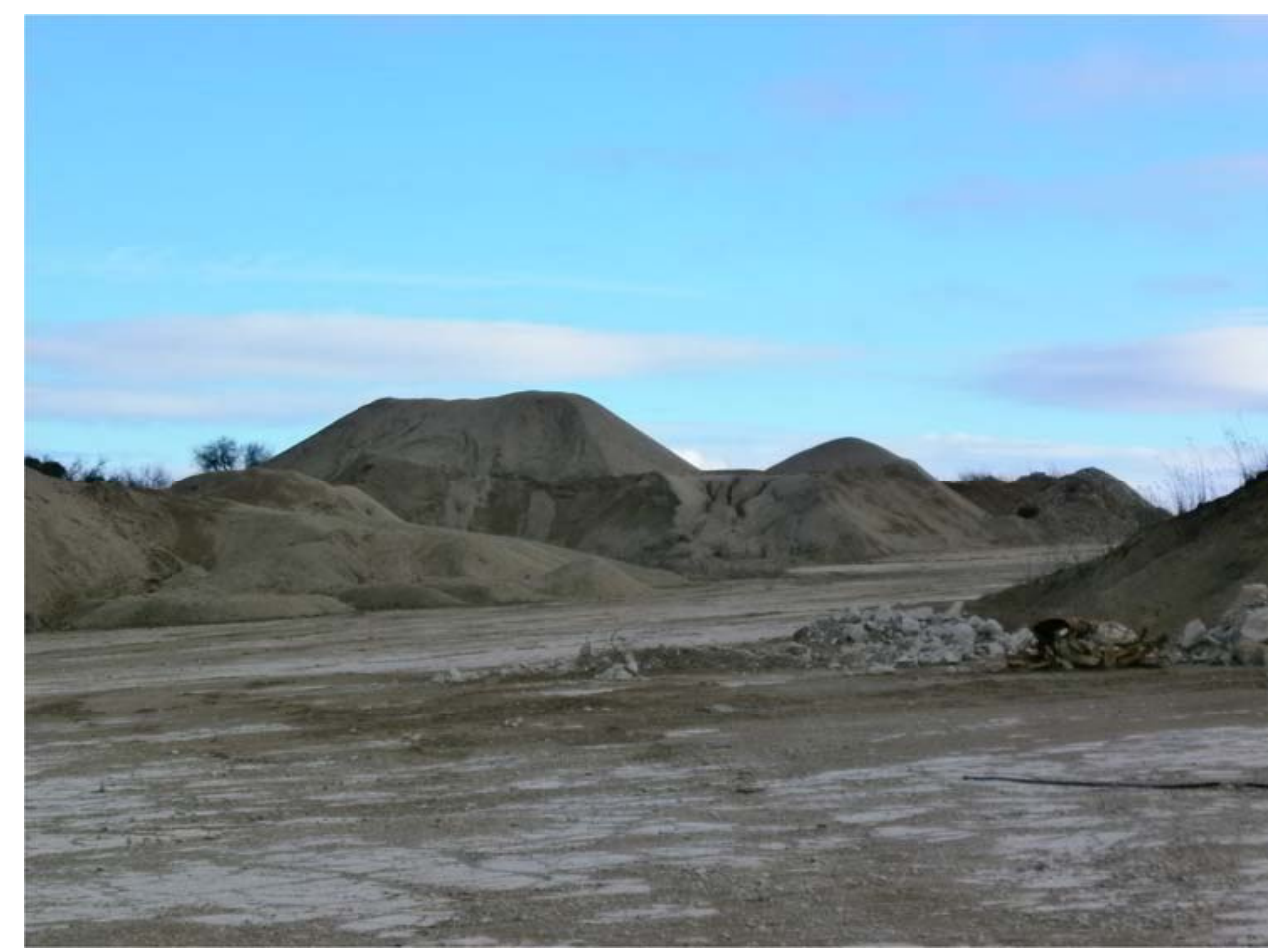

Fotografia 1. Aflorament i explotació de les calcàries de la Panadella

Pedrera de Carbassí - la Panadella 


\subsection{Parada 2 - CONDICIONAL. CARRETERA A CALAF, B - 100, (terme municipal de Montmaneu, comarca d'Anoia). (Full 390).}

Després de fer l'aturada anterior, ens caldrà agafar la carretera local BV - 2234, la qual es dirigeix cap a la Panadella, tot i que troba abans la carretera $B$ - 221. En arribar-hi, caldrà creuar la carretera nacional N - IIA i I'Autovia $A$ - 2. Així, ens caldrà agafar la carretera local $B$ - 100. Per aquesta, aviat arribarem a Montmaneu, des d'on ens caldrà continuar cap a l'ENE. Poc després de sobrepassar el darrer poble esmentat, podem fer una nova aturada. Així, haurem recorregut poc més de $5 \mathrm{Km}$ des de l'inici del recorregut.

En aquest recorregut, hem anat trobant afloraments dels materials carbonatats que pertanyen a la Formació Tàrrega. Aquests són els materials que es troben a l'indret on farem aquesta aturada.

Per altra banda, en aquest recorregut estem situats a la part més alta de la taula de la Panadella. Aquesta és una divisòria d'aigües. Prop d'on som neix el riu Sió, afluent del Segre, que se'n va cap a ponent. I també del riu Panadella, (afluent de I'Anoia), que se'n va cap a llevant. Per d'altra banda, des d'aquest indret, es pot gaudir d'una bona observació de les valls del dos rius.

\subsection{Parada 3. ANTIGA PEDRERA DE SEGUR, (Segur, terme municipal de Veciana, comarca d'Anoia, Alta Segarra Calafina). (Full 361).}

Després de realitzar la parada anterior, cal continuar cap a l'ESE per la carretera B - 100. Així aviat es deixarà la comarca de l'Anoia, passant momentàniament a la comarca de la Segarra. Aviat es passarà per la Tallada i posteriorment per les immediacions de Sant Guim de Freixenet. Poc després es tornarà a entrar a la comarca d'Anoia (encara que a la subcomarca de I'Alta Segarra). D'aquesta manera, es continuarà ara per la carretera local BV - 1001. Més endavant, en trobar el trencall que condueix cap el poblet de l'Astor, ens caldrà agafar-lo (es tracta de la carretera local BV - 1007).. A menys de $1 \mathrm{Km}$ del trencall, caldrà fer una nova aturada. Així, des de l'anterior, s' haurà fet un recorregut aproximat d'uns $5 \mathrm{Km}$, per tal d'arribar fins on ara som.

En aquest recorregut, hem anat trobant afloraments dels materials esmentats a les aturades anteriors; és a dir dels materials carbonatats de la Formació Tàrrega. Aquests són els materials que hi ha a l'indret de l'aturada.

En aquest lloc va haver-hi una explotació dels materials carbonatats, de les calcàries, per tal d'ésser emprades com a àrids per a la construcció. A l'actualitat l'explotació es troba totalment aturada. (fotografia 2). 


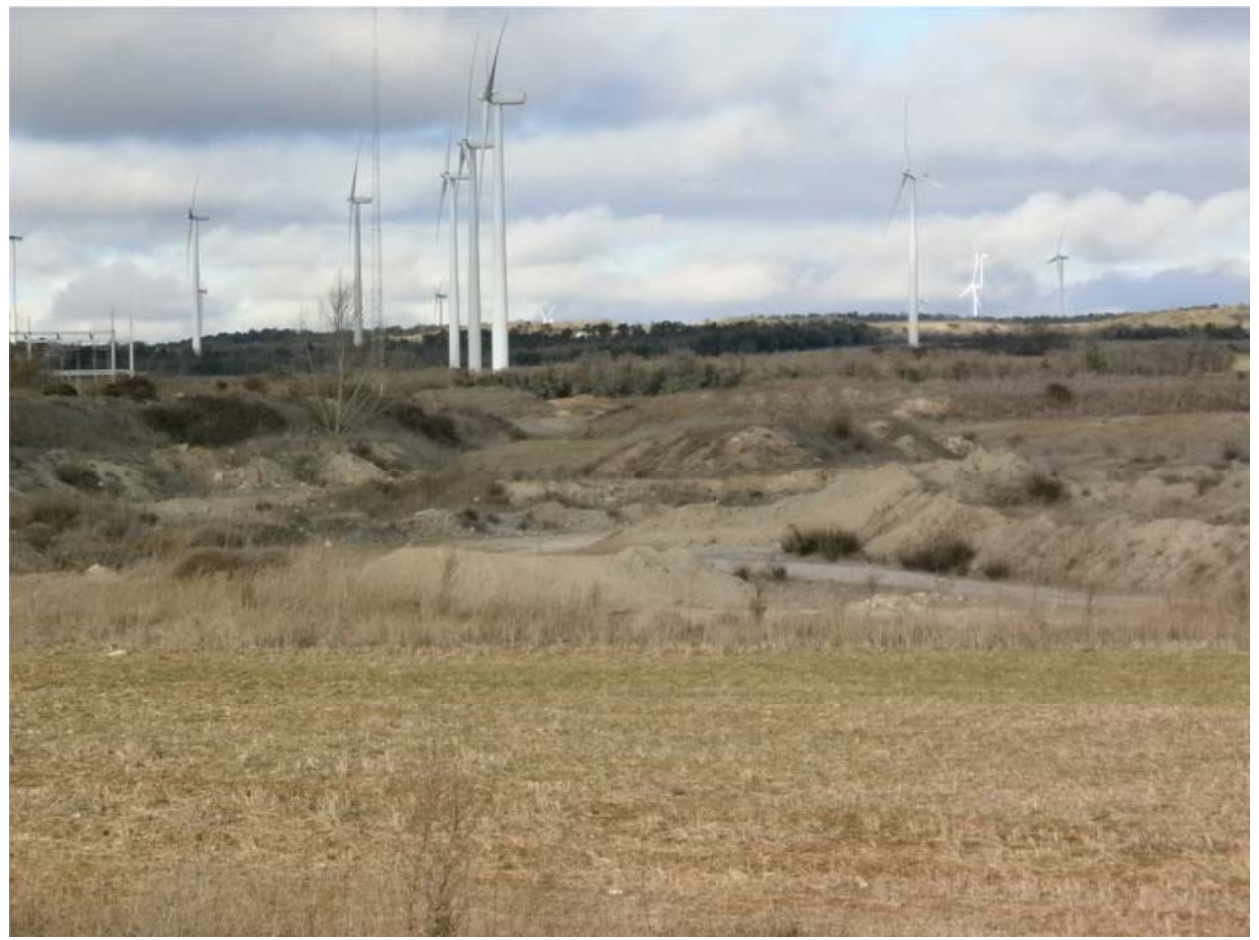

Fotografia 2. Antiga explotació de les calcàries de la Formació Tàrrega.

Pedrera de Segur, prop de l'Astor

\subsection{Parada 4 - CONDICIONAL. MINA DE LIGNIT DE SEGUR, (Segur, terme de Veciana, comarca d'Anoia, Alta Segarra Calafina). (Full 391).}

Després de fer la parada anterior, cal retornar cap a la carretera local BV - 1001, la qual ens va apropant cap a la població de Calaf. Així, aviat passarem per les immediacions del poble de Segur, que caldrà sobrepassar. En arribar al $\mathrm{Km} \mathrm{6} 5$, ens caldrà momentàniament deixar la carretera, per un camí que va cap a l'esquerra. Després de passar per sota de la via de la RENFE, arribarem a l'escombrera d'una antiga mineta de carbó. Aquí farem una nova aturada, a uns 5-6 $\mathrm{Km}$ de la parada anterior.

En aquest recorregut, hem continuat trobant afloraments dels materials carbonatats de la Formació Tàrrega, aquests són també els materials que apareixen a l'indret de l'aturada.

En aquest lloc va haver-hi una antiga explotació dels nivells de lignits,. Aquests es troben intercalats entre els materials de la Formació Tàrrega. Sovint, aquests lignits són ferruginosos; així, a partir de l'oxidació de la PIRITA i de la MARCASSITA, s'han format òxids de ferro (amb GOETHITA, limonítica) i sulfats de ferro (amb MELANTERITA). L'explotació es troba aturada des de fa força anys, i sols es fa palesa l'escombrera. (fotografia 3). 


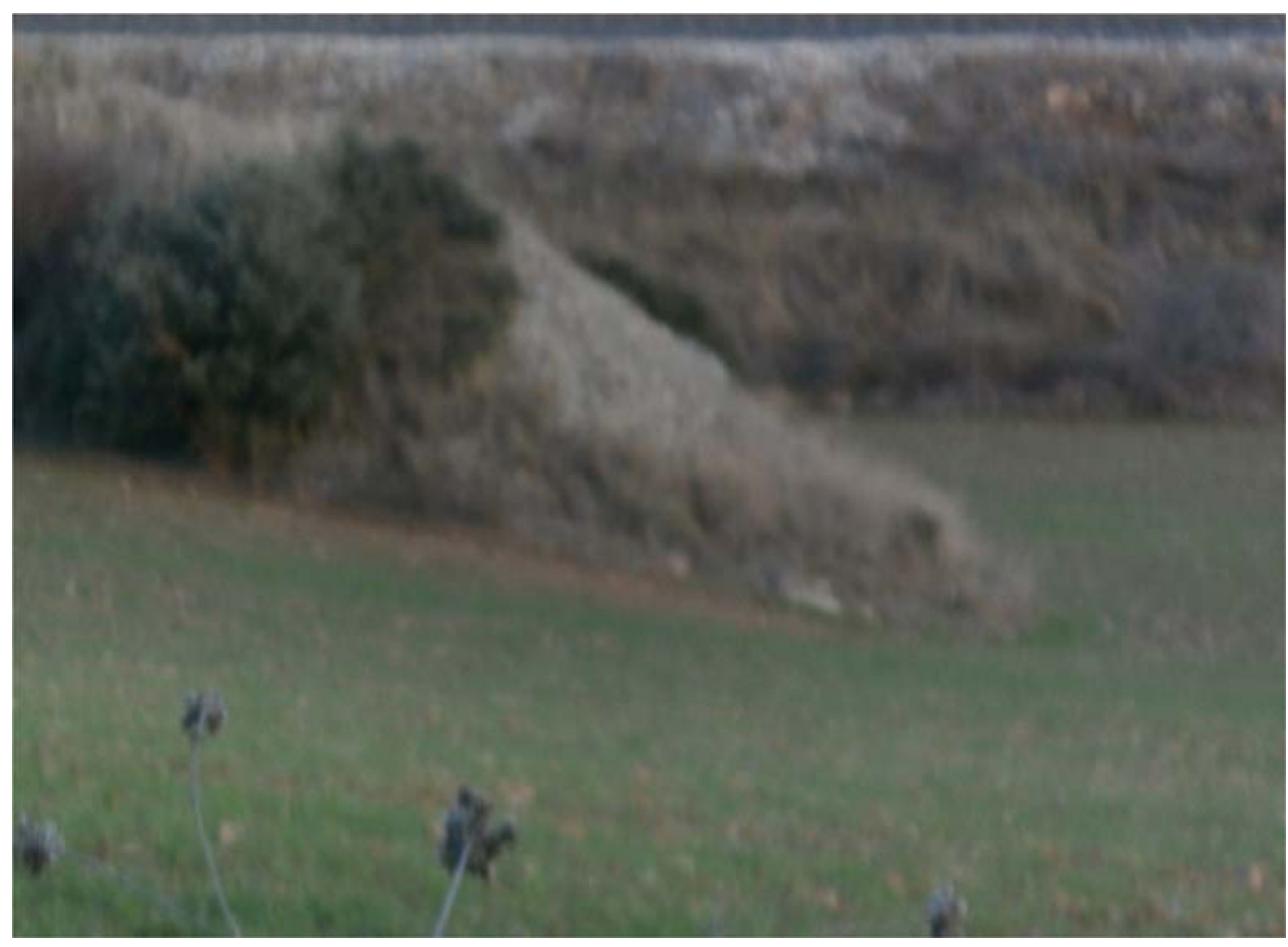

Fotografia 3. Restes de l'escombrera de lignit de la mina de Segur (Veciana)

\subsection{Parada 5. MINA A "CEL OBERT" DE LA GUARDIA (la Guàrdia Pilosa, del terme municipal de Pujalt, comarca d'Anoia, subcomarca de l'Alta Segarra Calafina). (Full 362).}

Després de realitzar l'aturada anterior, cal continuar cap a Calaf, per la carretera local BV 1001. En aquest recorregut, aviat es passarà per la població de Sant Martí de Sesgueioles, des d'on ens caldrà agafar el camí que es dirigeix cap a la Guàrdia Pilosa. Abans de començar la pujada es trobarà una antiga explotació lignitífera a cel obert. Aquí farem la present aturada, després de recórrer uns 1’5 Km des de la població esmentada inicialment. I a uns 4’5 Km de la parada anterior.

En aquest recorregut hem anat trobant afloraments dels materials calcolutítics (a filades més carbonatades, i d'altres més sorrenques) de la Formació Tàrrega. Es de destacar que sovint es fan força palesos els típics relieves en cuesta en tot aquest trajecte, a la bora dreta del mateix.

En aquest indret hi ha una antiga explotació dels lignits. aquesta explotació es va realitzar a cel obert, tot i la poca potència dels nivells lignitífers (amb un màxim de $20 \mathrm{~cm}$, normalment). Aquesta explotació va produir un greu atemptat contra el Medi Natural. A l'actualitat s'està intentant pal-liar aquest desgavell.

Així, cal fer un especial esment, en l'aspecte geo-ambiental, doncs les explotacions lignitíferes anteriors van provocar, en el seu temps, una gran destrossa ecològica, de la qual la zona no es troba encara restaurada, en la seva integritat, amb profundes cicatrius sense reblir.

També, per d'altra banda, al nostre entendre, va haver-hi uns errors greus alhora de realitzar l'explotació a "cel obert", ja que els nivells de lignit eren massa profunds, i calia explotar-los subterràniament. 
Entre els lignits de la Formació Tàrrega, es troben abundants mineralitzacions ferruginoses, amb la presència de: MARCASSITA, MELNIKOWITA i PIRITA (el més abundant dels tres), com a minerals primaris.

I també amb la presència d'abundants alteracions com: GOETHITA (limonítica), HEMATITES, FERROHEXAHIDRITA, MELANTERITA (el més abundant d'aquest grup), i SIDEROTIL. També es troben altres minerals, com la CALCITA i el GUIX.

\subsection{Parada 6. EXPLOTACIONS DE CALCOLUTITES DEL TURÓ DE SANT SEBASTIÀ, (terme municipal de Calaf, comarca d'Anoia, subcomarca de I'Alta Segarra). (Full 362).}

Des de la parada anterior, cal continuar cap al Nord, per tal d'arribar al poble de Calaf, la capital de la subcomarca. En arribar-hi, cal adreçar-se cap a les properes explotacions de calcolutites, a les quals es pot arribar des del carrer situat prop del Pas Subterrani sota de la via. En aquest indret, prop de les explotacions, i després de recórrer uns $4 \mathrm{Km}$, és on ens caldrà fer la present aturada.

En aquest recorregut, hem anat tallant els materials calcolutítics ja esmentats a la parada anterior. I, precisament en aquest lloc, aquests es troben en explotació, per tal d'ésser utilitzats en la fabricació de totxos i de ceràmica.

Pel que fa a l'explotació, cal dir que es força gran, i els materials extrets es porten cap a la propera fàbrica, situada a la bora de Calaf. Finalment, cal dir que per accedir a l'explotació, cal tenir necessàriament l'autorització de l'empresa (Ceràmiques Calaf S.A.). FOTOGRAFIES 4 i 5.

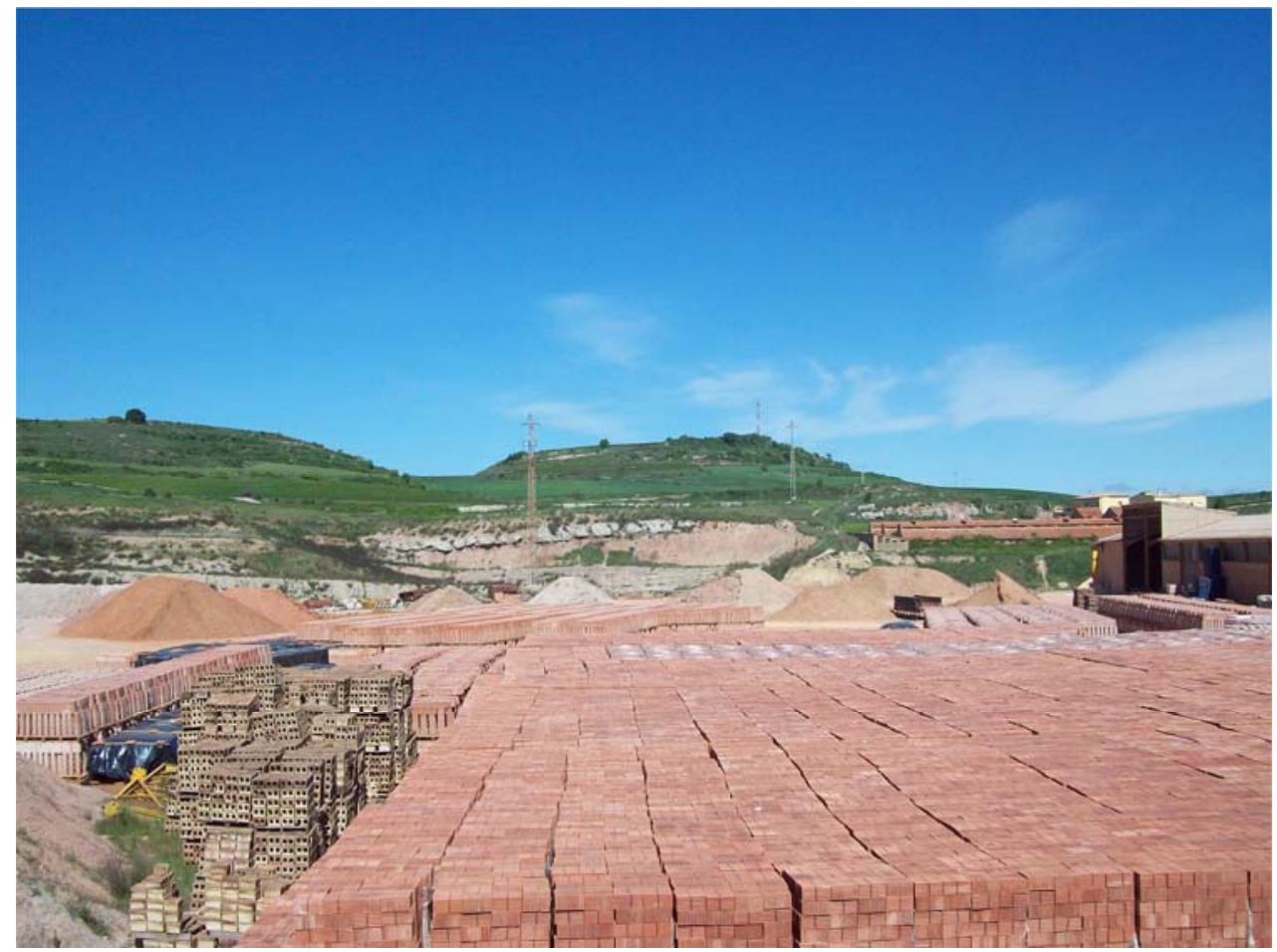

Fotografia 4. Vista general de ceràmiques Calaf 


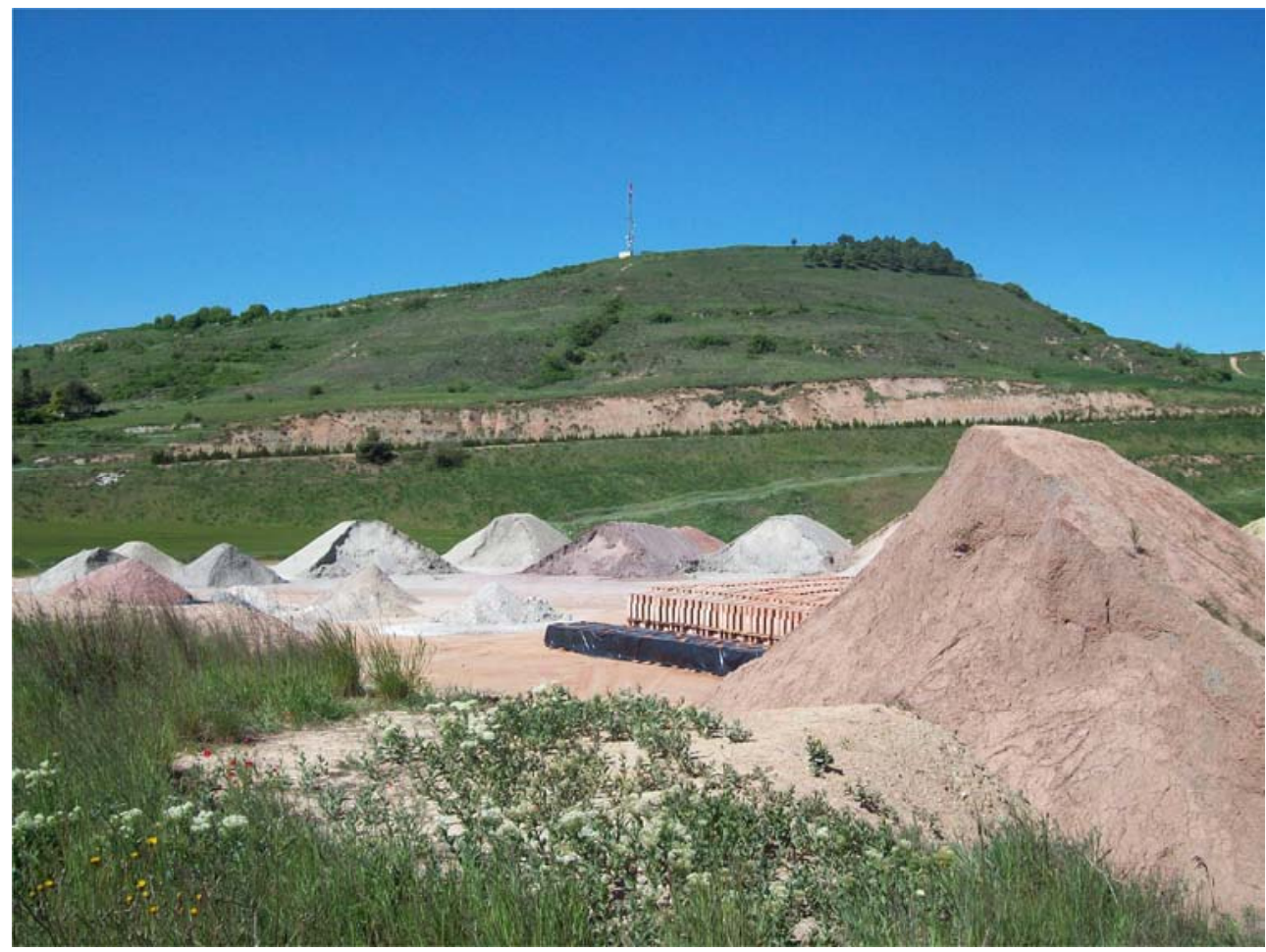

Fotografia 5. Vista general d'argiles procedents de diferents jaciments

En aquest indret finalitza el recorregut de l'itinerari.

\section{Bibliografia}

GUIMERÀ, J. et altri (1992).- Geologia (II), Història Natural dels Països Catalans, Vol.2, 547 pag. Enciclopèdia Catalana, S.A. Barcelona.

MATA - PERELLÓ, J.M. (1985).- Depressió de l'Ebre ?, Depressió Central ?. Revista Dovella, $n^{0} 15$, pp.45-48. Manresa.

MATA-PERELLÓ, J.M. (1990).- Inventari Mineralògic de la comarca d'Anoia. Revista Xaragall, $\mathrm{n}^{\circ} 24,40$ pag. Manresa.

MATA-PERELLÓ, J.M. (1991).- Els Minerals de Catalunya. Arxius de la Secció de Ciències, t. XCIII, 442 pag. Institut d'Estudis Catalans. Barcelona.

MATA-PERELLÓ, J.M. (1997).- Recorregut de recerca geològica i mineralògica per la Segarra i per I'Alta Segarra (Anoia): des de Sant Martí de Sesgueioles a Calaf i a Torà de Riubregós. Inèdit, 17 pàgines. Manresa.

MATA-PERELLÓ, J.M. (1999).- Recerca geològica per les comarques del Bages i de I'Anoia: des de Castellfollit de Riubregós a Rajadell i a Calaf. Algeps, sèrie $B, \mathrm{n}^{\circ} 118,11$ pàgines. Manresa. 
MATA-PERELLÓ, J.M. (2005).- Recerca geològica, minera i mineralògica per les comarques de I'Alta Segarra (Anoia) i de la Segarra: des de sant Martí de Sesgueioles a Calaf; i des de Durfort a Sant Ramon. Inèdit. 8 pag. Manresa.

MATA-PERELLÓ, J.M. (2007a).- Recorregut de recerca geològica, minera i mineralògica per les comarques de l'Alta Segarra (Anoia) i de la Segarra: des de Sant Martí de Sesgueioles a Calaf; i des de Durfort a Castellfollit de Riubregós, Ivorra i a Sant Ramon. Inèdit. 8 pàgines. Manresa.

MATA-PERELLÓ, J.M. (2007b).- Recorregut de recerca geològica, minera i mineralògica per les comarques de l'Anoia, l'Alta Segarra calafina (Anoia) i de la Segarra: des de la Panadella a Sant Martí de Sesgueioles, Calaf, Durfort i a Castellfollit de Riubregós. Inèdit. 10 pàgines. Manresa.

MATA-PERELLÓ, J.M. (2010).- Recorregut de recerca geològica, minera i mineralògica per les comarques de l'Alta Segarra Calafina (Anoia) i de la Segarra: des de Sant Martí de Sesgueioles a Calaf; i de Durfort a Castellfollit de Riubregós, Torà de Riubregós i a Ivorra. Inèdit. 16 pàgines. Manresa.

MATA-PERELLÓ, J.M. (2011).- Recorregut de recerca geològica, minera i mineralògica per la comarca de I'Alta Segarra Calafina (Anoia): des de Sant Martí de Sesgueioles a Calaf; i des de Durfort a Castellfollit de Riubregós. Inèdit. 12 pàgines. Manresa.

MATA-PERELLÓ, J.M. (2014).- Recorregut de recerca geològica i geoambiental per la comarca d’Anoia: des de la Panadella a Santa Maria del Camí i a Jorba. Inèdit. 8 pàgines. Manresa.

RIBA, O. et altri (1976).- Geografia Física dels Països Catalans, Edit. Ketres, 254 pàgines. Barcelona. 